\title{
Safe Space of Ideology
}

\author{
Wojciech Bartłomiej Zieliński \\ Pontifical University of John Poul II
}

\begin{abstract}
Our studies about safety in society lead us to the most popular book by Karl Mannheim: Ideology and Utopia. This work envisages the discrepancies between social knowledge and the material world itself. The crucial conclusion reads as follows: Our image of reality is mostly based on our interests and desires and does not rely on thorough research. There are two types of such representations: utopia and ideology. The first of them, less interesting for us, is the type of ideas which can revolutionize a social being. The second one is a particular set of visions which can never be realized but on the other hand they act as common knowledge (general knowledge of the world) - stabilizing the social structure by presenting it with a holistic image of the world. Taking the above into consideration, how is it possible that representations, being so distant from reality (creating a completely separate "world"), basically enable efficient functioning in it? Ideology, being the foundation of the society's functioning space, should always be tautological, in the sense that for the participants of the given world's image (creation as it is), it should define the being in a comprehensive and adequate way (in Thomas Aquinas spirit). What is more, it would always be true. We should also mention that the main tools of ideology, understood this way, are specific definitions and the extrapolation of sense. The purpose of this lecture is to prove that it is possible for ideology to come to life, only when the individuals who acknowledge it will consider their image of reality proper. The above ideological system should be understood as the obviousness of description of the surrounding world which in return makes unreflective functioning in reality possible. This obviousness of the presented world will be referred to as social safety.
\end{abstract}

Keywords: ideology, safety, knowledge, epistemology, Karl Mannheim, Karol Marx, linguistics

\section{Ideology as Knowledge}

The starting point for pondering over the notion of ideology—epistemological tool—is the Karl Manheim's concept of the sociology of knowledge. Two important points arise from the above. Firstly, Manheim, being a continuator of the Marxian thought, shows the "prevailing" material being (social being) as objectively existing (therefore, it is to be the point of reference - the source of cognition). Secondly, the classification of transcendental representations, namely, ideology is, together with utopia, a kind of representation which, thanks to the transcendence towards multi-aspectual and multi-dimensional matter, makes it possible to create holistic images. However, the specific character of ideology lies in the fact that its content never reaches realization in the material form. These are just representations that disguise reality in such a way that spotting the dissonance between the range of opinions of the world and the world itself is basically impossible.

Wojciech Bartomiej Zielinski, M.A., Faculty of Philosophy, Pontifical University of John Poul II, Poland; main research fields: Social Epistemology, Sociology of Knowledge, Phenomenology of the Politics, Social and Political Philosophy, Cognitive Linguistics, and Ideology and Utopia. E-mail: w.b.zielinski@wp.pl. 
Mannheim's proposition enumerates three ways of understanding the examined term. In addition to the general and overall meaning of ideology as the perspective of knowledge, we can also distinguish ideology as insincere mentality which enables us to detect differences between idea and reality (just as we may detect them in the structure enabling revolution). The last category mentioned by Mannheim is the deliberate lie ideology (the scope of ethics); this variant is outside our interest. ${ }^{1}$

The essential question we would like to answer here is: How is it possible that a representation, being so distant from reality (creating a completely separate "world"), basically enables efficient functioning in it?

Tautological aspect of ideology is the first hypothesis that may provide us with an answer. Ideology, being the foundation of the society's functioning space, should always be tautological, in the sense that for the participants of the given world's image (creation based on one's inner sense), it should define the being in a comprehensive and adequate way (in Thomas Aquinas spirit). What is more, it would always be true. The second hypothesis advocates that the main tools of ideology, understood this way, are specific definitions and the extrapolation of sense. It means that every new element of reality should be immediately defined in order to become an organic part of the whole system. Moreover, the political construction's main task is to create a mechanism which would be able to define all new elements using already existing pieces of knowledge, as every unknown element could be a potential threat to any stable social system. In other words, we may say that ideology creates a system and even if it is unable to stop changes and prevent new elements from appearing, they should be a realisation of the plan of metamorphoses. It also suggests that the authority is the core of social structures and every individual is a performer who puts the plan into practice in exchange for safety.

The consequences arising from the concepts initiated by Karl Marx and continued by Karl Manheim regarding the description of the society by means of epistemological theory concern mainly ideology. It will be hereafter presented as aspecific sphere of knowledge, the basis which is parallel to the definition of truth by Thomas Aquinas: Ideology is the adequacy of things and intellect; and a kind of everyday practice. It means that it is possible for ideology to come to life, only when the individuals who acknowledge it will consider their image of reality proper. The above ideological system should be understood as the obviousness of description of the surrounding world which in return makes unreflective functioning in reality possible. This obviousness of the presented world will be referred to as social safety.

The description constructed so far provides us with an initial definition of the notion which in the context of this project will be understood as safety (A situation where an ideology ceases to be safe may result in a revolution which is supposed to make changes in the axioms possible). This epistemological safety is therefore an indicator of ideological usefulness which is created with the use of various political and economic tools.

\section{Between Knowledge and Safety}

We should also focus on one additional aspect: the relationship between safety and knowledge. The first term does not belong to the fundamental features of knowledge ${ }^{2}$. What does it really mean that the knowledge is safe? Does the episteme meet requirements of safety? Firstly, let's attempt to define the character of safety. Most likely, we would immediately think of a mechanism which would be able to provide answers in any hypothetical reality - so to speak, in every possible world. In other words, if we name the colour of the wall in our bedroom e.g., green, we would like the name to be also understood in other similar realities. Duncan Pritchard, author of "Anti-Luck Epistemology," wrote about non-luckily true belief - a situation in which there is no accident and a belief is synonymous to confidence in the universal and infinite world of our knowledge. ${ }^{3}$ 
A similar situation was described by Kant in "Critique of the power of judgment," where the thinker proved that a subject has got aesthetic feelings towards some objects and they require everyone to agree with their likes or dislikes. ${ }^{4}$ It seems that we have a situation where a unit feels the very sureness of their judgment of taste; it is close to a belief - unwavering construction of an in-built picture of reality.

Secondly, our sketch of safety is coming closer to the understanding of the notion of episteme. All in all, knowledge of this kind should be inter subjective, constant and should fit various cases. Otherwise, it will become here and now. It actually resembles the status ideas hold in Platon's philosophy. In a way, we should believe that the episteme gives us the feeling of safety. On the other hand, as presented by Mannheim, this particular kind of knowledge - pure, universal construction in our intellects based on the world and tested by harsh reality - seems to be a de-humanized space with alien elements. Contemporarily, we all have a perfect shelter created by precise scientific methods which give us a certain picture of the world; however, it isolates us from our daily experience. ${ }^{5}$

Summing up, the proposition of Pritchard, where he envisaged a belief as the core of safety (knowledge), seems to be more convincing than the vision based on near-scientific epistemology. In fact, the second option requires also a special kind of belief mentioned by Quine in his "Ontology and Ideology, Revisited." We can also find an important conclusion in Terry Eagleton's book Marx and Freedom, namely the fact that knowledge functions as a historical event rather than as an abstract speculation in which "to know" is no longer clearly separable from "to know how." Although, we use our knowledge now, it—following Marx and Mannheim —is more contextual when immersed in its "historical life."

It would be the time we went one step further in our deliberations in order to notice a more basic matter. Categorical truisms, as suggested by Jan Srzednicki, are the ones that belong to it. These are kinds or parts of knowledge which cannot be questioned because if they were, it would be an attack on one's own rationality. ${ }^{6}$ It seems that the notion of belief is a part of this area. Our own rationality is not necessarily a global one or a scientific one. The way of defining the problem that we have undertaken slowly pushes us towards Mannheim's understanding of ideology. At the beginning, three ways of understanding the ideology by Mannheim were presented and now, using the proposition coined by Srzednicki, we will focus on the more holistic and fundamental meaning - Apekstruktur. This specifically-defined transcendental representation becomes the rule of safety.

There are also two additional, interesting conclusions that could come to our minds. The first one is an echo of Aquinas' definition of truth. Saint Thomas recognized intellect as a universal ability of humans, the same for everyone. The Marxian theory broke this proposition using the concept of ideology. There is no longer a pure, general skill of cognition - intellect is mixed with the group or individual interest. Therefore, there are many "worlds" whose coexistence we can describ by means of two theories: relativism and relationism. ${ }^{7}$ The first one shows the reality of many truths. We can call this situation a hard version of ideology; it means that any group of interests has its own truth - which is the core of this particular community (within this population, there are for example: extremists, fanatics). The second theory seems to be the light version, saying that every group is in relation with the truth. This is something, we could actually compare to a contest with finding out the truth as the goal. Sometimes, a seeming winner appears, such as the proletarian from the Marxian theory.

The next point of our discussion is ideology combined with politics as it was proposed by Mannheim. Yet, if we discuss this connection, we should not think in categories of propaganda. What does it mean? The state, understood as a political force, similar to the one in Hegel's theory of the spirit of the nation, has one 
fundamental function: to provide safety for citizens (based on a holistic picture of the reality). ${ }^{8}$ The tool used to fulfil this postulate is an ideology. At this point, many theories have been incorporated into this dispute. Apart from the above, we have the proposition of Michel Foucault concerning microfascism ${ }^{9}$ - a system that penetrates all aspects of social life and by doing so, it educates citizens and gives them a holistic and stable picture of reality. He suggests that the complete authority exists only when it can prevail ${ }^{10}$. From the proposed perspective, we should say that the authority will be stable if it creates a holistic picture of world. In other words, maybe we should think of an idea of the political force, a country or social group, responsible for our safety - what is interesting, not only at the military but at the knowledge level. What does it imply? Basing on the thinkers quoted above, we could say that the group should create the Hegel's spirit of nation which is good as it provides safety using "education" by means of ideology. The echo of this interpretation can also be found in a different proposition, i.e., "Clash of Civilisations" by Samuel Huntington.

\section{Ideological Society}

Let's now focus on describing the structure of the society based on ideology. It is defined as the knowledge which gives security. Such an approach allows establishing rules for constructing a society that will be derived from a related group - a unit. Moreover, we could create, on the basis of an epistemological context, an effective way of describing society and refer it to the theory regarding knowledge and truth. Our previous considerations suggest that the structural description of the society could be based on ideology. Such depiction allows us to establish rules of constructing the society and these will be derived from the relation group-individual. What is more, the goal of this approach is to create, on the basis of epistemological theory, an efficient method of describing the society. We assume that every individual cognises in a socially conditioned manner and therefore, a group influences their perception of the world (there is no such thing as extra-social cognition). The description of social construction is also based on the diversity of noological grounds (which is reflected by Marxian basis). We can also presume that the surrounding world is an infinite set of stimuli. On this set, we apply a notional framework which favours particular parts of the set and on this basis social groups are allocated. As a result, it is supposed to form a tool which will be used to describe the society (its structures). This description will focus on the relation, and in particular on the views based, on linguistic and ideological differences, which can be actually perceived as a kind of "war" between safety spaces.

Probably the most popular philosopher touching the topic of ideology is Marx. He determines the scope of interests related to ideology. First of all, it is to be understood in the Marxian context and many publications refer to it and the theory of ideology (as extensions). The proposed point of view refers mainly to the thought of Karl Mannheim which emphasizes the epistemological side of ideology. However, the research objective is to go one step further, namely to extend the pejorative understanding of ideology, in the context of false consciousness (knowledge-conditioned). The positive sense of space denotes functioning of the unit in reality and for reality (including its social dimension). The next step of our pondering is to ascend to the notion of social safety. The analysis of the construction by Karl Raimund Pooper, called the closed society, shows such mechanisms as planning economy, central state-management, resistance to change and group's awareness as the line of defence - the ideology's workspace.

It should be the food for thoughts here: What are the drawbacks of ideology? The answer seems simple: the propaganda and the system of lies. In fact, it does not add much to the social context we are interested in and by using such arguments, we fall into embroiled discussion about truth and its status. We had better focus 
on social aspects of the problem. Safety based on ideology has some consequences: There is no spontaneous development; and the development itself is an abstraction because planning is based on available elements only and the construction of the future is a variation of the elements from the past. Of course, we could have a situation where a new combination appears and it could be a discovery, but it would be way less dynamic. Another disadvantage here would be the mechanism of social knowledge: All our ideas are parts of the holistic world and both its background and sources are social. In consequence, there are no pure ideas - all of them are defected or even distorted by ideology. Therefore, even criticism is an organic part of a particular social reality. ${ }^{11}$ As we see, it is a kind of mental "golden cage:" Even if we could escape, do we want to?

\section{Conclusion}

Summing up, ideology as a major social mechanism provides safety by creating a holistic picture of the world - free from white semantic spaces. Everything is named and obvious, and reality can't surprise us: All answers are already planned. The presented proposition concerns a non-negative meaning function of ideology. Of course, it is not an ideal theory, yet you have to admit that it looks pretty interesting. And again, a major question should be asked here: Why is safety connected to ideology? Of course, our attractive proposition could be an answer, but let's look into source of this juxtaposition. The major purpose of this text is to present a social mechanism which is supposed to provide a feeling of safety. Following this path, the most universal and permeating tool is chosen - the picture of reality which we call knowledge. Next, a particular kind of this tool has to be found and here a theory by Basil Bernstein ${ }^{12}$ may become useful. The thinker said that language is a socializing force. Of course, as it shown in Bernstein's proposition, this instrument's influence reaches beyond the language level. So the most colloquial and pejorative meaning of ideology, as it was sketched before, is propaganda - a specific kind of language whose major task is to create a concrete meaning of the world. In Mannheim's book Ideology and Utopia, we can find a thesis that ideology has a non-negative meaning and is an organic part of our life associated with social sphere. ${ }^{13}$

As we can conclude from the mentioned examples, ideology itself is a non-global picture of the whole world; it is a vision dependent on local community which provides a possibility of creating an understandable and holistic rationality-internal micro-reality. In this text, it has been shown that this is actually the basis of our feeling of safety.

\section{Notes}

1. Vide, K. Mannheim, Ideology and Utopia, Vittorio Klostermann, Frankfurt am Main, 1995, 171-172.

2. Vide, P. Baumann, Is Knowledge Safe? American Philosophical Quarterly Vol. 45, No. 1, January 2008, 28.

3. Vide, http://christoph-kelp.com/download/Safety.pdf, 29. 08. 2014.

4. Vide, I. Kant, The Critique of Judgment, translate, J. Gałecki, PWN, Warszawa 1964, 43.

5. Vide, Mannheim, Structure of the Thinking, Routledge \& Kegan Paul, London, 1982, 185-186.

6. Vide, J. Srzednicki, Norm and Discerenment, WSiS UW, Warszawa, 2003, 26.

7. Vide, A. Schaff, Ideology in Mannheim's Perspective, Książka i Wiedza, Warszawa, 1956, 18-21.

8. Vide, K. Mannheim, Ideology and Utopia, Vittorio Klostermann, Frankfurt am Main, 1995, 62-63.

9. Vide, M. Żardecka-Nowak, The Freedom and Authority in Public Life, W. Zuziak, J. Mysona Byrska (ed.), WN PAT, Kraków 2008, 105.

10. Vide, C. Schmitt, Political Theology, Four Chapters on the Concept of Sovereignty, trans., G. Schwab, The MIT Press, Cambridge 1985, 19 and next.

11. K. R. Popper, Socjology of Konwlege, translate, A. Chmielecki, The Problems of the Sociology of Knowledge, A. Chmielecki, S. Czerniak, J. Niżnik, S. Rainko (ed.), PWN, Warszawa, 1985, 426-427. 
12. Vide, M. Marody, The Technologies of Intellect, Language Determinants of Common Knowledge and Human Actions, PWN, Warszawa 1987, 117 and next.

13. Vide, K. Mannheim, Ideology and Utopia, Vittorio Klostermann, Frankfurt am Main, 1995, 75 and next.

\section{Works Cited}

Chmielecki A., Czerniak S., Niżnik J., Rainko S. (ed.). The Problems of the Sociology of Knowledge. PWN, Warszawa: Polish Scientific Publishers Press, 1985. 426-39.

American Philosophical Quarterly Vol. 45, No. 1, January 2008, 19-30.

Kant I., The Critique of Judgment. Trans., J. Gałecki, PWN, Warszawa: Polish Scientific Publishers Press, 1964.

Mannheim K., Ideology and Utopia. Vittorio Klostermann, Frankfurt am Main: The Vittorio Klostermann Press, 1995.

Mannheim K., Structure of the Thinking. Routledge \& Kegan Paul. London: The Routledge \& Kegan Paul Press, 1982.

Marody M., The Technologies of Intellect, Language Determinants of Common Knowledge and Human Actions. PWN, Warszawa: Polish Scientific Publishers Press, 1987.

Schaff A., Ideology in Mannheim’s Perspective. Książka i Wiedza. Warszawa: The Book and Knowledge Press, 1956.

Schmitt C., Political Theology, Four Chapters on the Concept of Sovereignty. Trans., G. Schwab. Cambridge: The MIT Press, 1985.

Srzednicki J., Norm and Discerenment. WSiS UW, Warszaw: The Faculty of Philosophy and Sociology UW Press, 2003.

Zuziak W., Mysona Byrska J. (ed.), The Freedom and Authority in Public Life. WN PAT, Kraków, The PAT Scientific Press, 2008, 103-20. 